\title{
Euphemism and Hegemony: Discursive Power of Communication across Cultures
}

\author{
Pradeep K Sharma ${ }^{1 *}$ \& Mohammad Albarakati ${ }^{2}$ \\ ${ }^{1}$ Department of English, King Abdulaziz University, Jeddah (KSA), Saudi Arabia \\ ${ }^{2}$ Department of European Languages and Literature, King Abdulaziz University, Jeddah (KSA), Saudi Arabia \\ *Correspondence: E-mail: pk_atrey@yahoo.com
}

Received: March 23, 2019

Accepted: March 29, 2019 Online Published: March 31, 2019

doi:10.5430/elr.v8n1p55

URL: https://doi.org/10.5430/elr.v8n1p55

\begin{abstract}
The socio-political manipulation of euphemisms across cultures as alternate metaphors with ideological force has been analyzed in the present paper. The study was inspired by George Orwell's treatment of euphemisms as ideological tools for hedging, Lakoff and Johnson's idea of metaphors as elements structuring human thought and Roman Jakobson's model to study metaphor and metonymy as instances of romantic and realistic tendencies respectively in the user, and ordering of human behavior accordingly. A close analysis of the employment of euphemisms in differing social set-ups suggests that some euphemisms reveal a hegemonic impulse behind their usage, while a different category of euphemisms behave as counter-balancing force against this hegemonic impulse exerting dominance in a community. To comprehend the significance of this distinction better, the researchers suggest that in the existing categorization of euphemisms, two new categories - hegemonic euphemisms and resistance euphemisms - may be added.

Further investigation into the cultural function of euphemisms reveals that euphemisms function as signs of signs, therefore, meaningless words. The study concludes that such a usage of euphemisms is problematic since euphemistic expressions are capable of reducing (unwanted or undesirable) meaning as redundant, superfluous, and ineffectual to rouse human conscience.
\end{abstract}

Keywords: euphemisms, cultural hegemony, cultural capital, symbolic power

\section{Introduction}

Euphemisms are ideological constructs, declares George Orwell in Nineteen Eighty-Four (1949, p. 179). From conceptual perspective euphemisms are either metaphorical or metonymic devices. Both the figures of speech are inherently ideological. Conceptual Metaphor Theory, grounded in George Lakoff and Mark Johnson's work Metaphors We Live By (1980), asserts that the commonly held belief that metaphors are mere poetic, aesthetic and thus decorative devices and therefore only marginal elements in language and human thought, needs a serious review since metaphors play a crucial role in structuring and orienting human thought into particular patterns. The authors derive a number of tenets from the argument stated above. One of the tenets is that metaphors are ideological. Since euphemisms are semantic in general and often metaphorical, Conceptual Metaphor Theory endorses Orwell's view on embedded ideology in euphemistic expressions. ${ }^{1}$

\section{Research Questions}

Euphemism involves hiding something that is unpleasant to the conscious ego. The question arises: Is this human tendency a defense mechanism or instinctual repression acquired in course of evolution of culture, or is this linguistic camouflage sex-linked, as argues Mary Midgley in The Myths We Live By (2004, p. 88)? But, a more profound pattern in social behavior is also noticeable as hierarchized social groups, in an attempt to consciously suppress their subconscious motives, display the use of a typical selection of euphemisms in social interactions. The selection of euphemisms, it seems, depends upon the social status of the user, symptomatic of a prevailing power-structure in a given community and between communities. This observation prompted us to study the dynamics of intra-community as well as inter-community socio-cultural power-structure reflected in their use and constant shifting of euphemisms over time. This is the first dimension of our study. To this end, we designed our study keeping two broad research questions in view, as follows: 
1. Does euphemistic usage reflect the dynamics of social hierarchy and cultural power-structure (hegemony/resistance) in a community?

2. Accordingly, does it bear any significance in our realization of social / political issues if we look at euphemisms as orienting human perception towards hegemony or resistance?

The study of the first dimension may be helpful in exploring how particular euphemisms are used as hegemonic forces. In this analytical process we have also attempted to synthesize Roman Jakobson's (1956) idea of differing orientations of metaphorical and metonymic dimensions of language to shape man's world view - metaphor (similarity) leaning towards romanticism, whereas metonymy (congruity) towards realism - with the notion of ideological embedding in metaphorical and metonymic euphemistic usage in general. This is second dimension of the study, i.e., study of euphemistic expressions of differing nationalities in order to explore whether particular cultural expressions lean towards metaphorical or metonymic side of language use. This bears the potential to explain how the culture of a community affects communicative preferences, or in other words (in line with Roman Jakobson's interpretation of metaphors and metonymy), whether romantic preference or a realistic outlook towards life.

\section{Research Materials}

For our study we have used, in addiction to several other sources, George Orwell's two novels Animal Farm and Nineteen Eighty-Four as source texts to collect data on the apparently hegemonic euphemisms. Orwell has given a new dimension to euphemisms in his works highlighting the ideological embedding in euphemistic constructions, especially emphasizing the role of language in shaping human consciousness, and at the same time disagreeing with the notion that human consciousness is purely, and only, linguistic.

\section{Literature Review}

Scholars are in agreement that euphemisms are words or phrases considered more polite in referring to topics than their literal designation (Allan and Burridge 1991; Arif 2015; Beizaee and Suzani 2016; Edgecombe 1994; Fahnestock 2011; Linfoot-Ham 2005; Malone 2000; McGlone, Beck and Pfiester 2006; Stein 1998; Tenbrunsel and Messick 2004; Trinch 2001; Warren 1992). Euphemisms, in this sense, provide a softening veneer to speech (to be kind towards others, such as physically challenged and visually challenged are used to refer to people with bodily deformities and the blind people respectively. Advocacy for inclusiveness in language is part of this empathy, so, we have words like, chair(person), mail carrier, server, and so on, in vogue now). Euphemisms provide the speakers an alternate to talk of an experience which they may not be able to do without the alternative terms (such as, rape) (McGlone et al. 2006). Negotiating taboo words also fall in this defining category as taboo words are harsh to people's sensibility and need a softening veneer. Thus, most frequently, as observes Slovenko (2001, 2005), inoffensive or pleasant terms are substituted for topics that are considered taboo or stigmatized in society-especially those related to sex, body parts, and bodily functions. Euphemisms are also used to add beauty to one's speech, to beautify innuendo, for equivocation in speech, and so on.

All this is fine. The problem arises when euphemistic expressions are chosen to cover up lies, for deliberate hedging in speech and to appropriate and exercise linguistic power since discursive power of communication is capable of influencing and shaping human thought, worldview, grasp over reality and ultimately decision-making. Covering up of lies is a deliberate language choice to convey a message different from the realty and still stay safe. We believe no better example of this phenomenon can be found in the recent world history than the use of the term eugenics, for a racist agenda in the US and for genocide in Germany during the heydays of the Third Reich. ${ }^{2}$ We have picked up the term language choice from Fyke and Lucas (2013), who, explicating their use of the expression with reference to euphemisms in the speech of people in certain contexts, say that, "By language choices, we refer to "discursive moves" that occur in several ways, including deliberate planning to gain control over meaning-making in a particular context" (p. 3). So, if the Japanese Emperor Hirohito made a statement, "The war situation has developed not necessarily to Japan's advantage" to mean Japan's defeat and unconditional surrender to the Allies after the loss of 3 million lives, he was deliberately hedging his speech as he never used the words "defeat" or "surrender" in his address to the nation for fear of a military coup in his country (Allen and Polmar 2015).

Appropriation and exercise of communicative power - political, cultural and symbolic power - is the function of a particular type of euphemism which we may call hegemonic euphemism, construed as hedging in speech and providing symbolic power to the hegemon to impair critical thinking and decision-making ability of the hegemonized group. The use of hegemonic euphemisms is a deliberate discursive practice to control meaning-making in certain contexts. The phenomenon of control over meaning-making, especially by use of euphemistic expressions, is observed by scholars in various contexts. Larsson \& Lundholm (2010), for instance, note that, "...euphemism 
embedded in a particular context functions to shape reality and influence decision making" (p. 162). Bandura (1999), in a similar vein maintains that "activities can take on very different appearances depending on what they are called" (p. 195) and Stein (1998) almost warns us that euphemism has the power to background, conceal, and mask a variety of different deeds and behaviors.

Euphemisms may be categorized in various ways, such as euphemisms based on their ethical nature, thematic contents as well as their nature to mirror particular national characteristics. Euphemisms with ethical considerations are political lies and the ones oriented by kindness. Thematically, euphemisms may be shame-based, fear-based, courtesy-based, etc. (Abrantes 2005, p. 91). Euphemisms, on account of being conceptual metaphors, fall into both primary metaphors and complex metaphors categories. Primary metaphors derive from common bodily experiences, whereas complex metaphors blend primary metaphors and cultural practices (Gibbs, Lima and Francozo 2004; Grady 1997; Kövecses 2005; Lakoff and Johnson 1999). Primary metaphors tend to be more universal in contrast with complex metaphors that are culture-specific. Euphemisms may also be culture specific reflecting a particular national character. For instance, euphemisms chosen from American ethos may tend to represent a national yeaning for perfection- physical, emotional and otherwise, while the British euphemisms may lean towards mystifying the meaning in general as the British people enjoy circumlocution.

Luchtenberg (1985, p. 24, quoted in Antos et al. 2008) categorizes euphemisms in view of their functions in speech, and accordingly, he creates two major categories - concealing euphemisms and veiling euphemisms. Examples of concealing euphemisms are fear-based euphemisms or shame-based euphemisms. Concealing euphemisms take both speakers' and hearers' interests into consideration. Veiling euphemisms are more oriented to the speaker and his intentions. In the case of veiling euphemisms the hearer should have more euphemism awareness, a shared knowledge.

\section{Discussion}

A significant point to note in this connexion is that some euphemisms as metaphors reveal the embedded power structure in a society since, as particular word usage reveals the social status of the speaker, so does the use of a particular euphemism. ${ }^{3}$ The only difference between ordinary words and euphemisms in this case is that it is social hegemony that assigns common words a status, not the function of those words; whereas, in case of euphemisms it is their function that determines their status. Following this observation, a yet another categorization of euphemisms, we suggest, may help us realize the power structure in a society and the role of euphemisms in bringing about the desired change (pushed forward by the political establishment, or the hegemon, who may represent the political establishment or the mainstream cultural apparatus) on one hand and expression of resistance (opposition by the individual) on the other. The suggested categorization is 'hegemonic euphemisms' and 'resistance euphemisms' respectively.

Hegemonic euphemisms shape the worldview of the hegemonized populace, and in course of time these euphemisms, and the lies covered up, gain acceptance as the truth; that hegemonic force is the genesis of such euphemisms is forgotten and people accept their meanings as the established truth. Such euphemisms may circulate in a language at a particular point in time and help maintain the power of a social segment for long. Resistance euphemisms reflect common people's resistance to hegemony. In course of time, the fact that such euphemisms must have originated to register protest but people's defeat against stronger circumstances may have led to their surrender to the overpowering circumstances, is forgotten and the euphemisms circulate as the truth of life. However, it is not to be assumed by our categorization - people with power and powerless populace - that there exist monolithic classes of people with absolute power and absolutely powerless people. On the contrary, it depends upon what role one visualizes oneself in at a particular point of time and thus what euphemistic expression befits the moment, since power is a negotiated exercise that alternates according to people's negotiated relationships in a community. An ordinary man may feel powerless before a stronger individual, but the same man may be all powerful before his wife at home, or the other way round.

The hegemons can manipulate the value system and social norms of a community to gain a tacit consent and automatic endorsement of the community to their right to rule. ${ }^{4}$ We argue that hegemonic euphemisms are used by the political establishment, the pro-establishment press, and the petit (national) bourgeoisie, while resistance euphemisms are the weapons of the powerless, the marginalized and the anti-establishment press in a country. What we mean by 'resistance' here is the reaction of man to the situation where he feels powerless in the face of a force beyond his control, and in utter failure and defeat man consoles himself with a make-believe better situation, although deep in his psyche he wishes to fight against the oppressive conditions. It would be difficult to establish who gives currency to a particular euphemism at a particular time, but it is almost certain to conclude whose 
favourite euphemism it is - of the establishmentarians or the radicals.

We also argue that the use of hegemonic euphemisms does not involve the hearer's interest; rather it is presumed that the hearer, on account of accepting the superiority and legitimacy of the speakers' right, goes along their line of thought and has to learn the meaning the hegemonizing power gives to the euphemistic expression. The use of resistance euphemism involves hearers' interest and the user believes in the shared knowledge. The political establishment of a country, especially if it is or tends to be, dictatorial, uses hegemonic euphemisms since, on the one hand it uses coercion and on the other hand makes the coercion sound like cheerful agreement of people. A good example of this phenomenon can be the corporate euphemism right sizing or downsizing for firing people. George Orwell in Politics and the English Language (1968) writes that, "Political language- and with variations that is true of all political parties, from Conservatives to Anarchists -is designed to make lies sound truthful and murder respectable and to give an appearance of solidity to pure wind" (p. 139). A few political euphemisms that Orwell brings to the fore:

Defenceless villages are bombarded from the air, the inhabitants driven out into the countryside, the cattle machine-gunned, the huts set on fire with incendiary bullets: this is called pacification. Millions of peasants are robbed of their farms and sent trudging along the roads with no more than they can carry: this is called transfer of population or rectification of frontiers. People are imprisoned for years without trial, or shot in the back of the neck or sent to die of scurvy in Arctic lumber camps: This is called elimination of unreliable elements. Such phraseology is needed if one wants to name things without calling up mental pictures of them. (1968, p. 136)

The party of pigs headed by Napoleon in Animal Farm (Orwell 1945) and the political establishment in Nineteen Eighty-Four (Orwell 1949) use hegemonic euphemisms, and the intentions of the two are pretty clear - to camouflage their intentions and to dictate terms to the ruled public. A few examples from Animal Farm: expelled (kicked off), Snowball's expulsion (he was driven away violently), Wild Comrades' Re-education Committee (taming the untamed), Sacrifice (made by Napoleon to take upon himself the responsibility of the safety of the Farm after expulsion of Snowball), voluntary work (but absentees would have their rations cut half), special contribution towards the building of the windmill, stated categorically, capitulated (hens giving up their eggs) confessions, special decree, readjustment of rations; Father of all animals, Protector of the Sheep-fold, Ducklings' friend (all three used for Napoleon), taken away from (died), superannuated animals, certain measure of misgiving, and so on. These expressions exemplify hegemonic euphemistic force, while Sugarcandy Mountain (to denote heaven) is an example of resistance euphemism since the expression is used to make fun of the tall talk of the clergy who are generally in collusion with the establishment. ${ }^{5}$ The Newspeak in Nineteen Eighty-Four represents hegemonic euphemisms, and since the common people lack voice in the novel, they use only a few resistance euphemisms, such as memory hole (wipe out written memory to alter the past), steamer (rocker bomb), and wallop (cheap mild beer), etc.

From Jakobson's perspective, euphemisms in George Orwell's works can be studied as instances of metaphors (based on similarity) or metonymy (based on congruity). If metaphors, they reflect romantic leanings in the given culture (a tendency to postpone the immanent and embrace the idealized), whereas, if metonymic, the culture displays realism (embrace the immanent and not care for the idealized). For instance, Russia under Stalin, Germany under Nazis and Italy under Fascists, as obliquely represented by Orwell in the two novels, had a vision of a highly romanticized culture postponing (rather crushing) the immanent and embracing the idealized, even at the cost of genocide. The major bulk of their thought pattern was clothed in euphemistic metaphorical language, very rarely in metonymic expressions.

What social impacts do these two categories of euphemisms may have, apart from reflecting social hierarchy in a community? Most notably, they strengthen the inherent group cohesiveness and belonging essential to maintain cultural hegemony and status quo in a society. The use of the respective euphemisms by the corresponding social class - powerful or powerless - adds an element in the cultural capital of the class in question. Cultural capital, a term used by Pierre Bourdieu (1984), is anything apart from the financial capital like, education, intellect, speech, dressing sense, leadership qualities, public management abilities, etc., that add to individual or group benefits and productivity. The accumulated cultural capital bestows upon one (group) communicative power and status. Thus, it is easy to apprehend the subconscious motives of a class behind the use of hegemonic euphemisms, such as the ever-changing euphemism loo - from loo to toilet to lavatory to water-closet to rest-room, and perhaps a new one under construction. Resistance euphemisms are the cultural capital of the marginalized providing them psychological benefits and potential productivity at work. There cannot be anything inherently bad or low culture in the poor word loo and nothing inherently good or high culture in the word WC or rest room but it is interesting to note that loo in a 
British context will pass respectfully, whereas the use of the same word is frowned upon in the US. We stress that the implication is that in the US if you are using the word loo your social status is low and you are less cultured, and by implication the use of $W C$ or rest room accords you symbolic power and social status. The other interesting fact is that euphemistic usage may be a social requirement in Arabic societies since the list of taboo subjects - "the subjects that are socially recognized as inconvenient and require special care in discourse" (Abrantes 2005, p. 90) - may be fairly long in their case as compared to culturally open societies like in the Americas, yet Americans may be using more euphemisms than people in Arabic societies. What discomfort might Americans have with worlds like toilet? The four-letter sex word that is taboo in most Arabic societies is quite frequent in American usage, and does not generate discomfort in the native speakers, but why innocent words like toilet do? The question is: Is it the meaning of words and the emotions they evoke that prompt us to employ euphemisms or the associated feeling of social cohesiveness and cultural and symbolic power?

Hegemonic impulse is the underlying motive for many a euphemism for taboo words too. Social restrictions on the use of words is not an individual or subjective choice, but a social convention. Social conventions are politically and ideologically motivated, so, ultimately, taboos too are ideological constructs. The truth of this observation is proved by the fact that different societies observe different taboos since ideological apparatuses work differently in different social set-ups, though a few taboos are found to be universal in all human societies. Universalism in taboos may originate from shared human experience, while the genesis of other taboos lies in particularization of cultures. Belching in public, for instance, is a taboo in western societies, whereas, Indians may deliberately belch in public to show off that they had a fulfilling meal (a redundant legacy of the times when having a fulfilling meal was a luxury to be shown off) ${ }^{6}$

Prevalence of either hegemonic or resistance euphemisms in common linguistic usage can also be studied as one of the distinguishing features of differing cultures and national identities. Euphemism exists in all aspects of American English in great numbers (Li-na 2015, p. 266). Many American euphemisms tend to be hegemonic since their usage doesn't take hearer's interest into account. Another mark of embedded hegemony in their usage is that numerous American euphemisms are meaninglessly ambiguous words, or merely another signifier unilaterally replaced for the existing one: bathroom tissue (lavatory paper), dental appliances (false teeth), pre-owned (used or second hand items), wellness centre (hospitals), procedure (clinical operation), pre-elderly (persons of a mature age), senior citizen (the old), WC (water closet) and rest room, etc. We argue that they typically correspond to Orwell's Newspeak in Nineteen Eighty-Four where all the government departments have fancy names, such as, Ministry of Love, Ministry of Plenty, and so on. ${ }^{7}$ This brings to mind two possible prompts for the hegemonic impulse here - people's tendency to impose meaning upon new words, and a possible disgust with the reality, which may be psychologically repulsive or rather offensive, even obscene. ${ }^{8}$

British euphemisms, to a large extent, are hegemonic in nature since they too hardly take the hearers' interest into consideration. But, though a foreigner in England may be puzzled at how meanings beyond his/her comprehension are conveyed though euphemisms, the natives are at ease with them, or rather, have a pleasant feeling of complicity among themselves, which makes it yet another feature adding to their hegemonic nature. Newspaper obituary euphemisms like, convivial or cheery (a drunkard), sociable or ebullient (unbearably garrulous), lively wit (having a penchant for telling cruel and unfunny stories), austere and reserved (joyless and depressed), not to suffer fools gladly (having a foul temper), having notable vivacity (nymphomania), a confirmed bachelor (homosexual), thirsty (heavy drunkard), tired and emotional (visibly drunk), volatile personality (having terrible eruptions of temper), a courageous decision (career-crippling decision), adventurous (the worst decision, mad and unworkable) are well known in the British context. A frank discussion (a row), a robust exchange of views (a full-scale shouting brawl), plain (ugly looking), a bit slow for his/her age (low intelligence), soft in the head (mad), and taking things without permission (stealing) are also common.

Many Chinese euphemisms on the other hand are generally resistance euphemisms - a roundabout manner of talking about forbidden subjects. They do take hearer's interest into account and believe in the shared knowledge. The Chinese have great concern for old people, so they use very mild euphemistic expressions for them: old worker, old manager, old boss, and old brother, etc. (Qi 2010, p. 139). Euphemistic expressions, such as fang shi / room business (sex life), bu qingchu / I'm not clear (I'll not tell you anything), bu fangbian /not convenient (I'll not do it at all), yanjiu / let's research (give me some cigarettes and alcohol and I'll do your work) are common expressions heard from the Chinese officials.

Death euphemisms in Arabic are also generally resistance euphemisms since death is a defeating human experience and one can only console oneself that after death the departed has been elevated to a better place as the favoured one 
(of Allah). Galal (2014) notes ten different connotation of death euphemisms in Arabic: death is a better location (e.g., ista'thar Allah-bih /God favored him), death is life (e.g., rafa'ah Allah 'ilayh / God raised the deceased to Him), death is a summoner (e.g., labba nida' rabbih / He answered his Lord's call), death is accomplishment of one's vow (e.g., qadha nahbah / He accomplished his vow), life is a robe that gets torn by death (e.g., tasharrama hablu hayatih / The robe of his life is torn off), death is a destination (e.g., madha lisabalih / (He) reached his destination), death is loss (e.g., ihtabalahu himamuh / His fate hunted him with a rope), death is regrouping and joining with God (e.g., laqiya rabbah / Met his Lord), death is surrender and submission (e.g., istaslama liqadha'ai Allah / He surrendered to God's destiny), and death is sleep (e.g., raqada raqdatahu al'akhirah / He slept his last sleep) (pp. 159-164) - and it is worth noting that almost all the euphemisms reflect man's resistance to the inevitable but surrender to it because death is stronger than him, and self-consolation is the only alternative in the face of man's utter failure. The metaphors are all derived from everyday experience, especially from the power structures experienced in society that bind man all around, and the similar power structures may be found working their way through other resistance euphemisms as well. Surrender and self-consolation are reflections of a psychic process the genesis of which lies in man's sub-conscious resistance to unpleasant conditions. Even surrender to the Supreme Power (Allah) and the self-consolation in the thought that He treats the departed well because the departed has faithfully followed the path laid down by Him has its genesis in man's long-forgotten experience in the surrender to the socially / politically / economically powerful (kings, leaders, patriarchs), and the expectation of mercy, pardon for the sins, and good treatment at his hands in return for the faithfulness and loyalty. Political euphemisms, irrespective of the national character, are commonly hegemonic euphemisms, so in Arabic too political euphemisms bear the same character.

\section{Analysis and Interpretation}

Euphemism is ideological - it orients the speaker's consciousness from one concept to other, gliding from metaphor to metaphor (or metonymy), from signifier to signifier, though evading the signified in the process. The basic premise of this idea is the observation that we think in language, therefore, our thoughts are limited to the limits of human language. The evocative power of words which is exploited in euphemisms is closely related to the states of human consciousness and the images consciousness creates for itself to grasp what we commonly call as meaning. Human consciousness can, thus, be subtly guided to a desired state to create a desired image, a feature of human behavior exploited by the hegemons to their advantage, and the same feature put to use by the guided for self-consolation. It may follow from this that control over meaning-making through euphemisms provides an edge to the user. But, let's be clear at this point that language is not the only mode of meaning-making available to man, otherwise what would follow is the prejudiced notion that a language with limited vocabulary would provide its speaker with only a limited range of thought, and a language rich in vocabulary and finer shades of meaning of words provides its speakers a wider range of thought and knowledge. The corollary thought would be that the speakers of the language poor in words are less civilized as they lack many concepts in comparison to the speakers of another language with more words at its disposal. It would be a fallacy to assume that richness in lexicon provides a superior edge to a language since the assumption behind this argument is that human consciousness, knowledge and wisdom is subservient to linguistic consciousness. Linguistic consciousness is only a fraction of human consciousness. Language is one of the elements of culture, so theoretically it is possible that if the language of a community provides them with finer nuances of abstract thinking, the community may make more scientific and technical progress, but human knowledge and wisdom is reflected in non-linguistic modes as well.

There are two associated ideas worth considering at this juncture. First, euphemism presumes that human consciousness is linguistic. The meaning is that if an alternate escape form is available to the consciousness to assume, it assumes that form and represses the unpleasant. If the idea of death is unpleasant, an alternate linguistic construction kick the bucket, an expression nowhere related to death or only remotely related, provides the consciousness a pleasant form to assume and escape the unwanted. The understanding behind this thought is that language and thought are one, inseparable elements as are the recto and verso of a paper; it is not that there exists some objective reality and language is the medium to present the abstract reality into comprehensible concrete form. At the same time, it is not just the gross linguistic utterances that is meant by consciousness being linguistic, but also the pre-utterance spacing of sound and idea, and then the differentiation and recombination of sound segments into phonemes, morphemes, and lexemes, the primordial binary opposition of self and the other, the différance, spacing, trace and construction of the distinction between the idea and the words. Although we presume that linguisticism or languageing (the capability of consciousness to express itself through [vocal] sounds. Languageing is the characteristic feature of almost all living creatures, such as the birds chirp, animals make sounds, monkeys chatter/gibber, mice squeal, and so on; albeit human language is more advanced and complex $)^{9}$ is only a fraction of human consciousness, not the only form of consciousness available for human understanding, yet commonly it is the 
only part that forms the bulk of human communication. Thus, if a language community is oriented towards a particular understanding of certain expressions, its collective consciousness assumes that form and over a course of time accepts it the only truth. If the act of resistance to certain practices of the hegemonic force are euphemistically termed by the hegemon as terrorism, over a period of time they are accepted as such. That is what Bandura (1999: 195) means when he says that "certain euphemisms are powerful linguistic tools, or rather 'injurious weapons' that have serious consequences for people."

The second idea associated to the first is a question: Is euphemism a sign of a sign? Like in the examples given by Roman Jacobson, to an aphasic, the object pencil is not an object but a sign (like, to a normal man picture of a pencil is a pictorial sign, not the real object), and the word pencil is the sign of a sign, therefore redundant and superfluous to him. We have discussed above that euphemisms orient the speaker's consciousness from one concept to the other, gliding from metaphor to metaphor (or metonymy), from signifier to signifier, evading the signified in the process. Euphemisms are, therefore, sings of signs. Euphemisms are redundant and superfluous expressions, and thus, meaningless words as far as they are meant to replace other words. They are employed without direct involvement of consciousness, and are used to mean something without actually meaning it, otherwise, how would they successfully replace taboo words? What euphemism does (for example, hiding the unpleasantness in literalism) is secondary; the primary issue is what it does to the original expression (replaces the meaning of the expression with something different). Euphemism obliterates the original expression. Hegemonic euphemisms, from this perspective, are dangerous expressions as the meaning of the word/phrase which should have been originally in place is obliterated from human consciousness, and at the same time the new expression is reduced to be redundant and superfluous, sans consciousness and sans effect on the listener. Thus, in the example given by George Orwell, if we hear pacification for "defenceless villages being bombarded from the air, the inhabitants being driven out into the countryside, the cattle machine-gunned, the huts set on fire with incendiary bullets," it leaves no serious repercussions on our conscience as would have been left by something like brutal killing of civilians in air raids. Language actually covers our existence with ego-defense mechanisms, euphemisms being one of them.

\section{Conclusion}

The objective of this research has been to study the nature of euphemisms - their meanings, functions and categorization - with reference to social hierarchy and power-structure. The outcome of our investigation, in view of our research questions, indicates that some euphemisms are found to reveal the hierarchical power structure embedded in the linguistic usage of a community and that there is a particular category of euphemisms, commonly used by people in power, which induce (a group of) people to think in a particular fashion, in return enhancing the cultural capital and symbolic power of the user social group to derive higher social status and better (material) benefits. Accordingly, we suggest a different way of looking at a particular category of euphemisms, and suggest that they may be categorized as hegemonic euphemisms and resistance euphemisms. The suggested new categories of euphemisms may help us realize the hidden power structure and social hierarchy within a community and between communities.

The function of some euphemisms goes beyond face-saving owing to shame, fear or courtesy, and they are also not employed to hide something unpleasant to the conscious ego. Such euphemisms reflect the hierarchical and discursive power hidden in the communicative function of human language that the use of these linguistic expressions bestows upon the user a form of hegemonic control over the intended meaning and thus wield some symbolic power in the community which shares that language. On the other hand, people on the other side of the social spectrum find some counter-hegemonic euphemistic expressions to resist the impacts of this unwanted accumulated cultural capital as well as symbolic power. There exists a balance between the two at a given point of time, but serious issues may arise if hegemonic euphemisms or resistance euphemisms are taken to be the general truths of life, as for example, serious social problems do crop up if some euphemisms are employed to cover up blatant lies. The point here is: euphemisms are double-edged weapons. In the hand of the powerless, they are powerful as they can express themselves without being caught off guard. But in the hands of the powerful they are the weapons of a change brought about in the thinking pattern of the less dominant. The use of euphemisms, it seems, has increased overtime, with the advent of political correctness and academic hedging.

\section{References}

Abrantes, Ana M. (2005). Euphemism and co-operation in discourse. In Eric Grillo (ed.), Power without Domination: Dialogism and the Empowering Property of Communication, 85-106. Amsterdam: John Benjamins Publishing Company. https://doi.org/10.1075/dapsac.12.05abr

Allan, Keith, \& Burridge, Kate. (1991). Euphemism \& Dysphemism: Language used 
as a shield and weapon. New York: Oxford University Press.

Allen, Thomas B., \& Polmar, Norman. (2015). The Radio Broadcast that Ended World War II. The Atlantic, August 7, 2015.

Antos, Gerd, Ventola, Eija. \& Weber, Tilo. (2008). Handbook of Interpersonal Communication, HAL 2. Berlin: Mouton de Gruyter. https://doi.org/10.1515/9783110211399

Arif, Narmina. (2015). Social and cognitive implications of using euphemisms in English. International Journal of English Linguistics 5(6). 151-156. https://doi.org/10.5539/ijel.v5n6p151

Bandura, Albert. (1999). Moral disengagement in the perpetration of inhumanities. Personality and Social Psychology Review 3(3). 193-209. https://doi.org/10.1207/s15327957pspr0303_3

Beizaee, Mehran, \& Suzani, Samad M. (2016). A semantic study of English euphemistic expressions and their Persian translations in Jane Austin's novel Emma. International Academic Journal of Humanities 3(11). 41-53.

Bhartrhari. (1994). Vakyapadiya [On words and sentences] $\left(4^{\text {th }}\right.$ C., AD), trans. K. A. Subramania Iyer. Poona: Deccan College.

Bourdieu, Pierre. (1984). Distinction: A Social Critique of the Judgment of Taste. Cambridge, MA: Harvard University Press.

Clark, L. D. (1980). The Minoan Distance: The Symbolism of Travel in DH Lawrence. University of Arizona Press.

Eagleton, Terry. (1991). Ideology: An Introduction. London: Verso.

Edgecombe, Rodney S. (1994). Violence, death and euphemism in Great Expectations. Victorians Institute Journal 22(1994). 85-98.

Fahnestock, Jeanne. (2011). Rhetorical style: The uses of language in persuasion. Oxford: Oxford University Press. https://doi.org/10.1093/acprof:oso/9780199764129.001.0001

Fyke, Jeremy, \& Lucas, Kristen. (2013). Euphemisms and ethics: A language-centred analysis of Penn State's sexual abuse scandal. Journal of Business Ethics 114(4). 1-45.

Galal, Mohamed M. (2014). Death euphemism in English and Arabic: A conceptual metaphorization approach. International Journal of Linguistics 6(1). 153-170. https://doi.org/10.5296/ijl.v6i1.4514

Gibbs, Raymond W., Lima, Paula, \& Francozo, Edson. (2004). Metaphor is grounded in embodied experience. [Special issue on metaphors]. Journal of Pragmatics 36(7). 1189-1210. https://doi.org/10.1016/j.pragma.2003.10.009

Grady, Joseph. (1997). Foundation of meaning: Primary metaphors and primary scenes. (Unpublished $\mathrm{PhD}$ dissertation), University of California, Berkeley. Open access publications. https://escholarship.org/uc/item/3g9427m2

Gramsci, Antonio. (1992). Prison Notebooks (edited by Joseph A. Buttigieg). New York: Columbia University Press.

Granofsky, Ronald. (2009). "His father's dirty digging": Recuperating the masculine in DH Lawrence's Sons and Lovers. Modern Fiction Studies 55(2). 242-264. https://doi.org/10.1353/mfs.0.1615

Grillo, Eric (ed.). (2005). Power without Domination: Dialogism and the Empowering Property of Communication. Amsterdam: John Benjamins Publishing Company. https://doi.org/10.1075/dapsac.12

Jakobson, Roman. (1990). Two types of language and two types of aphasic disturbances. In Roman Jacobson (1956), On Language (edited by Linda R Waugh and Monique Monville-Burston) (Chapter 7). Massachusetts: Harvard University Press.

Kinhead-Weakes, Mark. (1968). The marble and the statue: The exploratory imagination of DH Lawrence. In Ian Gregor and Maynard Mack (eds.), Imagined Worlds: Essays in Honour of John Butt. London: Methuen.

Kövecses, Zoltán. (2005). Metaphor in Culture: Universality and Variation. Cambridge: Cambridge University Press. https://doi.org/10.1017/CBO9780511614408

Kuttner, Alfred B. (1916). Sons and Lovers: A Freudian Appreciation. The Psychoanalytic Review 3(3). http://ecmd.nju.edu.cn (accessed on 23.05.2018).

Lakoff, George, \& Johnson, Mark, (2003/1980). Metaphors We Live by. Chicago: The University of Chicago Press. https://doi.org/10.7208/chicago/9780226470993.001.0001 
Lakoff, George, \& Johnson, Mark. (1999). Philosophy in the Flesh: The Embodied Mind and its Challenge to Western Thought. New York: Basic Books.

Larsson, Magnus, \& Lundholm, Susanne E. (2010). Leadership as work-embedded influence: A micro-discursive analysis of everyday interaction in a bank. Leadership 6(2).159-194. https://doi.org/10.1177/1742715010363208

Lawrence, David H. (1913). Sons and Lovers. London" Gerald Duckworth \& Co. Ltd.

Lawrence, David H. (1915). The Rainbow. Hertfordshire: Wordsworth Classics (1995).

Lawrence, David H. (1920). Women in Love. New York: Random House (2002).

Lawrence, David H. (1928). Lady Chatterley's Lover. New York: Bantam Books (Reprint, 1968).

Li-na, Zhou. (2015). Euphemism in modern American English. Sino-US English Teaching 14(4). 265-270.

Linfoot-Ham, Kerry. (2005). The linguistics of euphemism: A diachronic study of euphemism formation. Journal of Language and Linguistics 4(2). 227-263.

Lombardo, Paul A. (ed.). (2011). A Century of Eugenics in America: From the Indiana Experiment to the Human Genome Era. Bloomington: Indiana University Press.

Malone, C.N. (2000). Near confinement: Pregnant women in the nineteenth-century British novel. Dickens Studies Annual 29. 367-385.

Manto, Sa'a:dat Hasan. (2016). Kali Salwar and Other Stories [Black trousers and other stories]. New Delhi: Rajpal \& Sons.

McGlone, Matthew S., Beck, Gary, \& Pfiester, Abigail. (2006). Contamination and camouflage in euphemisms. Communication Monographs 73(3). 261-282. https://doi.org/10.1080/03637750600794296

Macleod, Sheila. (1985). Lawrence's Men and Women. London: Heinemann.

Midgley, Mary. (2004). The Myths We Live By. London \& New York: Routledge.

Orwell, George. (1945). Animal Farm. London: Secker and Warburg.

Orwell, George. (1949). Nineteen Eighty-Four. London: Secker and Warburg.

Orwell, George. (1968). Politics and the English language. In Sonia Orwell and Ian Angos (eds.), The Collected Essays, Journalism and Letters of George Orwell, vol. 4, edn. 1, 127-140. New York: Harcourt Brace.

Qi, Guo. (2010). Cultural differences in Chinese and English euphemisms. Cross-Cultural Communication 6(4). 135-141.

Schneider, Daniel. J. (1986). The Consciousness of DH Lawrence: An Intellectual Biography. Lawrence, Kansas: University Press of Kansas.

Shakespeare, William. (1610-11). The Tempest. www.shakespeare-online.com

Slovenko, Ralph. (2001). The pervasiveness of sex and excretory language/a lexicon. Journal of Psychiatry \& Law 29(2). 201-270.

Slovenko, Ralph. (2005). Commentary: Euphemisms. The Journal of Psychiatry \& Law 33(4). 533-548. https://doi.org/10.1177/009318530503300411

Stein, Howard F. (1998). Euphemism, Spin, and the Crisis in Organizational Life. Westport, CT: Quorum Books.

Tenbrunsel, Ann E., \& Messick, David M. (2004). Ethical fading: The role of self-deception in unethical behavior. Social Justice Research 17(2). 223-236. https://doi.org/10.1023/B:SORE.0000027411.35832.53

Tharoor, Shashi. (2017). Inglorious Empire: What the British Did to India. London: Hurst \& Co Ltd.

Trinch, Shonna L. (2001). Managing euphemism and transcending taboos: Negotiating the meaning of sexual assault in Latinas' narratives of domestic violence. Text 21(4). 567-610. https://doi.org/10.1515/text.2001.012

Warren, Beatrice. (1992). What euphemisms tell us about the interpretation of words. Studia Linguistica 46(2). 128-172. https://doi.org/10.1111/j.1467-9582.1992.tb00833.x 


\section{Notes}

1 A word denotes primary meaning. Another referent for the same word is an instance of metaphor. If a given word is replaced by a new word that still refers to the meaning denoted by the first word - it would be an instance of euphemism. Thus, there is a difference between metaphors and euphemisms. Metaphor is an instance of one word having multiple referents, whereas euphemisms is an instance of one referent having multiple words, one to be replaced by the other, though the secondary word functions as a metaphor now since it already denotes a referent and the new referent added to it is only its secondary meaning. The other difference is that metaphoricity is limited to secondary or at the most tertiary meanings of words, while euphemism can be endless as long as a community grasps the same referent through varying words. Loo, lavatory, toilet, WC, washroom, restroom, bathroom ... all are words for a single referent in a single language.

${ }^{2}$ Eugenics was in practice in America too and, although Lombardo (2011) notes that,

Many people are still shocked to hear that practices such as eugenic sterilization began in the United States long before they were taken up in totalitarian settings such as Nazi Germany. Because of the power of that historical trajectory, a linkage is assumed - both too often and too quickly - between anything "eugenical" and the rise of the Third Reich. (p. 1)

yet, the program in the US also was a racist agenda.

${ }^{3}$ It is commonplace for creative writers to portray word usage as one of the socio-cultural distinguishing features of different fictional characters. Caliban in The Tempest uses words different from Prospero \& co.; and DH Lawrence is well-known for creating male characters in his novels peculiarly distinctive from their female counterparts mostly on the basis of word usage (see Lady Chatterley's Lover; The Rainbow; Sons and Lovers; Women in Love). Lawrence scholars, especially the psychoanalysts who have studied Lawrence from Freudian perspective, believe that Lawrence's male characters are based on his father's character who was a coal miner and therefore used the dialect of English that was coarse from higher cultural standards. The most impressive study of DH Lawrence from Freudian perspective is Alfred Booth Kuttner's (1916) review of Sons and Lovers (accessible from http://ecmd.nju.edu.cn). Some notable works on the same lines are: Kinhead-Weakes, M. (1968); Clark, L. D. (1980); Macleod, S. (1985); Schneider, D. J. (1986); and Granofsky, R. (2009).

${ }^{4}$ We have used Antonio Gramsci's (1992) notion of 'hegemony,' to whom, in the words of Terry Eagleton (1991), hegemony is the manner in which a dominant power appropriates the consent to its dominance from those it dominates. British rule in erstwhile colonies was initially established by hook or by crook (In India they played the policy of 'divide and rule.' See Shashi Tharoor (2017), Inglorious Empire: What the British Did to India), but afterwards it was sustained through cultural hegemony - the colonized readily accepted the cultural, political and technical superiority of the colonizer and the rulers gained a tacit mass consent.

${ }^{5}$ Animal Farm in itself is a metaphor (but a negative euphemistic expression) and denotes an example of propaganda politics. Prominent metaphorical expressions from Animal Farm are:

Old Major, ensconced, fallen on evil days (become alcoholic), expelled (kicked off), Snowball's expulsion (he was driven away violently), Wild Comrades' Re-education Committee (taming the untamed), sacrifice (made by Napoleon taking upon himself after expulsion of Snowball), voluntary work (but absentees would have their rations cur half), special contribution towards the building of the windmill, capitulated (hens giving up their eggs) confessions, special decree, readjustment of rations, Father of all animals, Protector of the Sheep-fold, Ducklings' friend, taken away from (die), superannuated animals, certain measure of misgiving, and so on.

${ }^{6}$ Sa'a:dat Hasan Manto (2016), a notable Urdu short story writer, portrays an interesting character Chaudhary Moju, a simple villager in his story 'Sahib-e-Qara:ma:t,' who is untouched by any kind of euphemism. He performs all simple rituals for the village community. On the death of a young man the obituary he offered runs like this:

What a robust and handsome young lad he was! If he spat, it would fall twenty yards away! And there was no one in all the villages and towns around to match the force of the stream of his urination! .... (p. 107) 
${ }^{7}$ Newspeak in Nineteen Eighty-Four is primarily oriented to dissuade people from using a language in which words have evocative dimensions and therefore affect human conscience. Attempts were made to keep the new language free from signifieds, to be made up of only signifiers; so, it has to be comprised of only euphemisms. Orwell writes -

No word in the B vocabulary was ideologically neutral. A great many were euphemisms. (1949, p. 179)

Almost invariably these words - goodthink, Minipax, prolefeed, sexcrime, joycamp, Ingsoc, bellyfeel, thinkpol, and countless others - were words of two or three syllables, with the stress distributed equally between the first syllable and the last. The use of them encouraged a gabbling style of speech, at once staccato and monotonous. And this was exactly what was aimed at. The intention was to make speech, and especially speech on any subject not ideologically neutral, as nearly as possible independent of consciousness. For the purposes of everyday life it was no doubt necessary, or sometimes necessary, to reflect before speaking, but a Party member called upon to make a political or ethical judgment should be able to spray forth the correct opinions as automatically as a machine gun spraying forth bullets. (1949, p. 180)

A few notable examples of euphemisms from Nineteen Eighty-Four are as follows:

Victory Mansions/gin/cigarettes, Telescreeen, The Party (the dictator and his cronies), memory hole (to wipe out written memory to alter the past), Big Brother, Thought Police (an organization forcing people to think only on Party lines), Ministry of Truth (controlled the media, to destroy history; Newspeak, Oldspeak (common language), Ministry of Peace, Ministry of Plenty (economic affairs), free market, doublethink (holding contrary views at the same time; a perverse situation of maintaining double standards, and that is where the metaphor lies), Enemy of the People, spies and saboteurs, thoughtcrime, vaporized, unorthodoxy (radicalism), mutability of the past, Reality Control, slips/errors/misprints/misquotations (information to be removed through forgery), purge, new happy life (controlled and regulated life), facecrime, making a baby (sex), ownlife, confession, reclamation centres (for orphans, homeless), crimestop (stupidity), joycamp (forced labour camps), comintern, and so on.

${ }^{8}$ Victorian women in England were very fond of dogs as pets, and they used to keep their dogs fully clothed. There goes the story of a woman who was shocked to see her guest's dog without clothes and shouted, 'shame, shame!'

9 The idea languageing has been adopted from an ancient Indian linguist-philosopher Bhartrhari (4 ${ }^{\text {th }}$ C. AD), who maintains that the linguistic faculty in man is on the same level as are the instincts in other creatures. Bhartrhari observes:

The linguistic instinct in man is on the same level with the instincts in animals. It is this instinct or pratibha (a flash if intuition) that prompts living beings to act. What makes the cuckoo sing in spring? What teaches the spider to weave its web or the birds to build their nests? It is this same instinct that prompts man also. Every activity is based on this linguistic urge. (Vakyapadiya, II, p. 150) 